Volume. 5 Number. 2

Period: July - December 2021; page 69-75

p-ISSN : 2580-1112; e-ISSN : 2655-6669

Copyrighr@2020

The author owns the copyright of this article

journal homepage: https://ejournal.akperfatmawati.ac.id

DOI : 10.46749/iiko.v5i2.71
Jurnal IImiah Keperawatan Orthopedi (JIKO)

Article history:

Received: January 28, 2022

Revised: February 11, 2022

Accepted: February 13, 2022

\title{
Family Nursing Care In Hypertension Disease With Nursing Problems Knowledge Deficit With Hypertension Health Education Actions
}

\author{
Ria Ika Imelda ${ }^{1,}$ Al-Bahra ${ }^{2}$ \\ Harum Nursing Academy, Jakarta-Indonesia ${ }^{1}$, Master in Informatics Engineering- Rahraja \\ University, Tangerang Indonesia ${ }^{2}$ \\ e-mail: ria.ika.imel@gmail.com ${ }^{1}$, albahra@ raharja.info ${ }^{2}$
}

\begin{abstract}
The purpose of this study was to determine Family Nursing Care for Hypertension with Knowledge Deficit Nursing Problems with Hypertension Health Education Actions. The research design is descriptive which aims to describe important events that occur in the present. The type of descriptive research design used is a case study research design. The case study subjects consisted of 2 (two) patients. The focus in the case study is to find out family nursing care in hypertension with the problem of lack of knowledge with health education actions about hypertension. The appropriate ones are: knowledge deficit related to the inability of the family to recognize sick family members. At the intervention stage, the author prepares a nursing care plan for Mr. S and Mr. A, which is to provide health education about hypertension. When this health education was given, respondents followed the directions given to make traditional treatment from star fruit to lower blood pressure. To determine the level of success of nursing actions that provide Health Education. Mrs. S got results before giving Health Education, Ny.S blood pressure was $145 / 80 \mathrm{mmHg}$ and after Health Education, blood pressure was 140/80 mmHg. While Mrs. A got the results before explaining Health Education, Mr. A's blood pressure was $140 / 80 \mathrm{mmHg}$ and health education was carried out with the results of blood pressure $135 / 80 \mathrm{mmHg}$.
\end{abstract}

Keywords: Family Nursing Care; Hypertension, Knowledge Deficit; Hypertension Health Education

\section{Introduction}

Hypertension is one of the noncommunicable diseases and diseases with major health problems in the world, even every year cases of hypertension are increasing. Data from the World Health Organization (WHO) in 2025 will increase hypertension. Around 1.6 billion people will be affected by hypertension (Syarifah, 2018). Riskesdas data in 2018 the prevalence of hypertension in Indonesia ranks $9(34.1 \%)$ this is an increase of about $8.3 \%$ in 2013 the incidence of hypertension in Indonesia $(25.8 \%)$ in a period of 5 years. The prevalence of hypertension in Indonesia currently ranks first, namely South Kalimantan (44.1\%) (Ministry of Health, 2018).

DKI Jakarta is the capital city of Indonesia with the highest population density in Indonesia with a value of 15,328 people $/ \mathrm{km} 2$ (Central Bureau of Statistics, 2015). Along with the density of the population, the risk of hypertension can increase. Based on Riskesdas data in 
2013 and 2018, the prevalence of hypertension in DKI Jakarta Province increased from $25 \%$ to $34.1 \%$ (Riskesdas, 2018).

Hypertension is a disease that cannot be cured but can be controlled so that there is no increase in blood pressure so that it does not cause complications of stroke, cardiovascular disease, and others (Fries, 2019). Public knowledge about the management of hypertension is still lacking at this time. Health education is one of the methods used to increase knowledge, health education is a process that can improve a person's health status. Health education can be given to all targets, but must use the right method so that the information that can be given is well received (Zakiyatul, 2017).

Some of the causes of high blood pressure, one of which is an unfavorable lifestyle that can trigger uncontrolled high blood pressure and continue to increase so that it is at risk of complications. The high incidence of hypertension cases requires health workers to continue to do prevention by providing health education to people with hypertension about the causes and triggers of an increase in blood pressure and conducting regular health checks on areas suffering from hypertension so that people can control hypertension. Muhammad, 2018). Based on cases of hypertension in Indonesia, it shows that hypertensive patients do not know how to manage hypertension properly. Management of hypertension properly is about a hypertension diet, the need for appropriate exercise, lifestyle modification, the need for knowledge about stress management, the importance of antihypertensive treatment and blood pressure control (Rahayu, 2019) with the title Health Education on Hypertensive Disease.

These data show that only $0.7 \%$ of people diagnosed with high blood pressure take hypertension medication.
Hypertension that does not get proper treatment causes complications such as stroke, coronary heart disease, diabetes, kidney failure and blindness. Stroke $(51 \%)$ and Coronary Heart Disease (45\%) are the highest causes of death. In addition, hypertension occurs mostly at the age of 35-44 years by $6.3 \%$, at the age of $45-54$ years by $11.9 \%$, and at the age of 55-64 years by $17.2 \%$. Meanwhile, according to economic status, the highest proportion of hypertension is at the lower middle level (27.2\%) and middle (25.9\%), Journal of Nursing Vol 12 Number 2, December 2019.

The role of health workers is to provide health education that can increase knowledge so as to make people believe what has been conveyed, and the public is aware that health education is provided for the public to know and understand about hypertension. But it is also expected that the community will be willing and carry out a recommendation that has been given from health workers so that patients and families can determine a deeper attitude in treating hypertension to improve their health status, Efforts to prevent the occurrence of diseases and complications. As well as maintaining health status, maximizing functions, roles and families to overcome health problems in sufferers (Warsono, 2017).

Based on the above background, researchers are interested in conducting research on family nursing care for hypertension with the problem of lack of knowledge with health education actions about hypertension in the family of Mr. S, especially Mrs. S and Mrs. Tanjung Priok District, North Jakarta.

The purpose of this study was to determine Family Nursing Care for Hypertension with Knowledge Deficit Nursing Problems with Hypertension Health Education Actions in Tn.S's 
family, especially Mrs. Papanggo Kec. Tanjung Priok, North Jakarta.

\section{Method}

The research design is descriptive which aims to describe important events that occur in the present. The type of descriptive research design used is a case study research design. The case study in this study is "Family Nursing Care for Hypertension with Nursing Problems Knowledge Deficit with Hypertension Health Education Actions in the Family of Mr. S especially Mrs. . Papanggo district. Tanjung Priok, North Jakarta".

The case study subjects consisted of 2 (two) patients. The focus in the case study is to find out family nursing care for hypertension with the problem of lack of knowledge with health education actions about hypertension. The instrument of this case study uses interviews, observations, documentation studies, questionnaires, sphygmomanometer and stethoscope, as well as tools for complementary therapy. The rating scale used in this paper is using a questionnaire.

\section{Results}

Table 1. General data of respondents 1 and 2 with cases of lack of knowledge of hypertension in Rt.006/Rw.003 Kelurahan Papanggo, Tanjung Priok District, North Jakarta.

\begin{tabular}{|c|c|c|}
\hline General Data & Respondent 1 & Respondent 2 \\
\hline $\begin{array}{l}\text { Name of the head of the } \\
\text { family }\end{array}$ & Mrs. S & Mrs. A \\
\hline Gender & Woman & Woman \\
\hline Age & 44 years old & 31 years \\
\hline Last education & senior High School & senior High School \\
\hline Work & Housewife & Housewife \\
\hline Address & $\begin{array}{l}\text { Papanggo IIB No. } 64 \text { Rt.006/Rw.003 } \\
\text { Papanggo Village, Tanjung Priok } \\
\text { District, North Jakarta }\end{array}$ & $\begin{array}{l}\text { Papanggo IIB No. } 65 \text { Rt.006/Rw.003 } \\
\text { Papanggo Village, Tanjung Priok } \\
\text { District, North Jakarta. }\end{array}$ \\
\hline
\end{tabular}

Table 2. Health care function (Phase II assessment)

\begin{tabular}{|l|l|l|}
\hline Maintenance Function & \multicolumn{1}{|c|}{ Case 1 } & \multicolumn{1}{|c|}{ Case 2 } \\
\hline $\begin{array}{l}\text { Recognizing health } \\
\text { problems }\end{array}$ & $\begin{array}{l}\text { 1) Mr. Family S especially Mrs. S said he } \\
\text { didn't know about his illness. } \\
\text { 2) Mr. Family S especially Mrs. S said he did } \\
\text { not know the causes and complications that } \\
\text { could result from hypertension }\end{array}$ & $\begin{array}{l}\text { 1) Mr. Family S especially Mrs. A said he } \\
\text { did not know about his illness. } \\
\text { 2) Mr. Family S especially Mrs. A said he } \\
\text { did not know what the cause, what food } \\
\text { and drink were caused by hypertension. }\end{array}$ \\
\hline Make decisions & $\begin{array}{l}\text { Mr. family S especially Mrs. S said that if the } \\
\text { family is sick, the family decides to } \\
\text { immediately bring to the nearest health center } \\
\text { or health service }\end{array}$ & $\begin{array}{l}\text { Mr. family S especially Mrs. A said that if } \\
\text { the family is sick, the family decides to } \\
\text { immediately bring to the nearest health } \\
\text { center or health service }\end{array}$ \\
\hline $\begin{array}{l}\text { Caring for family } \\
\text { members }\end{array}$ & $\begin{array}{l}\text { Mr. family S said he did not know how to } \\
\text { treat family members with hypertension at } \\
\text { home. If Mrs. S is having a headache and gets } \\
\text { tired easily just rest and sleep }\end{array}$ & $\begin{array}{l}\text { Mr. family S said he did not know how to } \\
\text { treat family members with hypertension at } \\
\text { home. If Mrs. A is having a headache and } \\
\text { gets tired easily just rest and slee }\end{array}$ \\
\hline $\begin{array}{l}\text { Modify } \\
\text { environment }\end{array}$ & $\begin{array}{l}\text { The area where Mr. There are many children } \\
\text { who like to play with a sound that is loud } \\
\text { enough to disturb the rest of Mrs. S }\end{array}$ & $\begin{array}{l}\text { The area where Mr. There are many } \\
\text { children who like to play with a sound loud } \\
\text { enough to disturb Mrs. A }\end{array}$ \\
\hline $\begin{array}{l}\text { Take advantage of } \\
\text { health facilities }\end{array}$ & $\begin{array}{l}\text { Mr. family T especially Mrs. S said that if the } \\
\text { family is sick, they always go to the health } \\
\text { center }\end{array}$ & $\begin{array}{l}\text { Mr. family T especially Mrs. S said that if } \\
\text { the family is sick, they always go to the } \\
\text { health center for treatment. }\end{array}$ \\
\hline
\end{tabular}


Table 3. Implementation of Nursing Actions

\begin{tabular}{|c|c|c|}
\hline $\begin{array}{c}\text { Execution } \\
\text { Day }\end{array}$ & Case-1 & Case-2 \\
\hline Day 1 & $\begin{array}{l}\text { Saturday, } 04 / 09 / 2021 \\
\text { 1. At } 16.00 \mathrm{WIB} \text { reviewing TTV } \\
\text { 2. Assess the client's level of knowledge. } \\
\text { 3. Assessing the level of pain }\end{array}$ & $\begin{array}{l}\text { Saturday, } 04 / 09 / 2021 \\
\text { 1. At } 17.00 \text { WIB reviewing TTV } \\
\text { 2. Assess the client's level of knowledge } \\
\text { 3. Assessing the level of pain }\end{array}$ \\
\hline Day 2 & $\begin{array}{l}\text { Sunday, } 05 / 09 / 2021 \\
\text { 1. At } 07.00 \text { WIB reviewing TTV } \\
\text { 2. Assess the client's level of knowledge } \\
\text { 3. Teach pain level } \\
\text { 4. Teach health education about hypertension }\end{array}$ & $\begin{array}{l}\text { Sunday, } 05 / 09 / 2021 \\
\text { 1. At } 07.00 \mathrm{WIB} \text { reviewing TTV } \\
\text { 2. Assessing the level of pain } \\
\text { 3. Teach pain level } \\
\text { 4. Teach health education about hypertension }\end{array}$ \\
\hline Day 3 & $\begin{array}{l}\text { Monday, 06/09/2021 } \\
\text { 1. At } 17.00 \text { WIB observing TTV and level of } \\
\text { knowledge } \\
\text { 2. Observing the level of understanding }\end{array}$ & $\begin{array}{l}\text { Monday, 06/09/2021 } \\
\text { 1. At } 18.00 \mathrm{WIB} \text { observing TTV and level of } \\
\text { knowledge } \\
\text { 2. Observing the level of understanding }\end{array}$ \\
\hline
\end{tabular}

Table 4. Evaluation

\begin{tabular}{|c|c|c|}
\hline Day & Case-1 & \\
\hline Day 1 & $\begin{array}{l}\text { S: } \\
\text { 1. Mr. Family S especially Mrs. S says headache and } \\
\text { discomfort } \\
\text { 2. Mr. family. S especially Mrs. S said he didn't know } \\
\quad \text { about hypertension } \\
\text { O: } \\
\text { The client looks grimace and looks confused } \\
\text { BP: } 145 / 88 \mathrm{mmHg} \\
\mathrm{N}: 73 \mathrm{x} / \mathrm{minute} \\
\mathrm{RR}: 20 \mathrm{x} / \mathrm{minute} \\
\mathrm{S}: 36 \mathrm{C} \\
\text { Pain scale: } 4 \\
\text { A: } \\
\text { 1. Acute pain } \\
\text { 2. Knowledge deficit } \\
\text { Q: } \\
\text { 1. Observation of TTV and assess the level of pain } \\
\text { 2. Provide health education about hypertension }\end{array}$ & $\begin{array}{l}\text { S: } \\
\text { 1.Mr. Family S especially Mrs. S says headache } \\
\text { and discomfort. } \\
\text { 2.Mr. Family } S \text { especially Mrs. A said he didn't } \\
\text { know much about hypertension } \\
\text { O: } \\
\text { The client looks grimace and looks confused } \\
\text { BP: } 140 / 70 \mathrm{mmHg} \\
\mathrm{N}: 84 \mathrm{x} / \mathrm{minute} \\
\mathrm{RR}: 20 \mathrm{x} / \mathrm{minute} \\
\mathrm{S}: 36 \mathrm{C} \\
\text { Pain scale: } 4 \\
\text { A: } \\
\text { 1. Acute pain } \\
\text { 2. Knowledge deficit } \\
\text { Q: } \\
\text { 1.Observation of TTV and assess the level of pain } \\
\text { 2.Provide health education about hypertension }\end{array}$ \\
\hline Day 2 & $\begin{array}{l}\text { S: } \\
\text { 1. Mr. Family } S \text { especially Mrs. S said he still feels } \\
\text { pain at the nape of the neck } \\
\text { 2. Mr. Family } S \text { especially Mrs. S said he started to } \\
\text { understand about hypertension } \\
\text { O: } \\
\text { 1. The client is able to explain again about the } \\
\text { meaning and causes of hypertension } \\
\text { 2. Clients are able to re-practice deep breathing } \\
\quad \text { relaxation techniques and music therapy } \\
\text { BP: } 140 / 77 m m H g \\
\text { N : } 88 x / \text { minute } \\
\text { RR: } 20 x / m i n u t e \\
\text { S: } 36 \text { oC } \\
\text { Pain scale: } 3 \\
\text { A: } \\
\text { 1. Acute pain } \\
\text { 2. Knowledge deficit } \\
\text { Q: } \\
1 . \text { Observation of TTV and assess the client's level of }\end{array}$ & $\begin{array}{l}\text { S: } \\
\text { 1. Mr. Family } S \text { especially Mrs. A says he still } \\
\text { feels pain at the nape of his neck } \\
\text { 2. Mr. Family } S \text { especially Mrs. } S \text { said he started } \\
\text { to understand about hypertension } \\
\text { O: } \\
\text { 1. The client is able to explain again about the } \\
\text { meaning and causes of hypertension } \\
\text { 2. Clients are able to re-practice deep breathing } \\
\quad \text { relaxation techniques and music therapy } \\
\text { BP: } 135 / 71 \text { mmHg } \\
\text { N : } 79 x / \text { minute } \\
\text { RR: } 20 x / \text { minute } \\
\text { S: } 36 \text { oC } \\
\text { Pain scale: } 3 \\
\text { A: } \\
\text { 1. Acute pain } \\
\text { 2. Knowledge deficit } \\
\text { Q: } \\
\text { 1. Observation of TTV and Assess knowledge }\end{array}$ \\
\hline
\end{tabular}




\begin{tabular}{|c|c|c|}
\hline Day & Case-1 & Case-2 \\
\hline & $\begin{array}{l}\text { knowledge } \\
\text { 2. Observation of pain level }\end{array}$ & $\begin{array}{l}\text { level } \\
\text { 2. Observation of pain level }\end{array}$ \\
\hline Day 3 & $\begin{array}{l}\text { S: } \\
\text { 1. Mr. Family S especially Mrs. S says the pain is no } \\
\text { longer felt } \\
\text { 2. Mr. Family S especially Mrs. S said he understood } \\
\text { about hypertension } \\
\text { O: } \\
\text { 1. The client looks calmer } \\
\text { 2. The client is able to explain the signs and symptoms } \\
\text { of hypertension complications } \\
\text { 3. Clients are able to re-practice traditional starfruit } \\
\text { infused water treatment. } \\
\text { BP: } 140 / 70 \text { mmHg } \\
\mathrm{N}: 79 \mathrm{x} / \text { minute } \\
\text { RR: } 20 x / \text { minute } \\
\mathrm{S}: 36 \mathrm{C} \\
\text { A: } \\
\text { 1. Knowledge deficit } \\
\text { 2. Acute pain } \\
\text { Q: } \\
\text { 1. Intervention discontinued } \\
\text { 2. Instruct the client to regularly check his condition to } \\
\text { the health service }\end{array}$ & $\begin{array}{l}\text { S: } \\
\text { 1.Mr. Family S especially Mrs. S says the pain is } \\
\text { no longer felt } \\
\text { 2.Mr. Family S especially Mrs. A says he } \\
\text { understands about hypertension } \\
\text { O: } \\
\text { 1.The client looks calmer } \\
\text { 2.The client is able to explain the signs and } \\
\text { symptoms of hypertension complications } \\
\text { 3.Clients are able to re-practice traditional } \\
\text { starfruit infused water treatment. } \\
\text { BP: } 135 / 80 \text { mmHg } \\
\text { N : } 80 x / \text { minute } \\
\text { RR: } 20 x / m i n u t e \\
\text { S: } 36 \mathrm{C} \\
\text { A: } \\
\text { 1. Knowledge deficit } \\
\text { 2. Acute pain } \\
\text { Q: } \\
\text { 1.Intervention discontinued } \\
\text { 2.Instruct the client to regularly check his } \\
\text { condition to the health service }\end{array}$ \\
\hline
\end{tabular}

\section{Discussion}

\section{Assessment}

The study on Ny.S was by direct interview technique to get focus data that Mrs. S said he did not know much about hypertension and did not know the causes and complications that could arise from hypertension. The study on Mrs. A, namely by direct interview technique, got focused data that Mrs. A said she did not know about hypertension and did not know the causes and complications that could arise from hypertension. So that based on the theory that has been described and the results of the study that the author got, there was no gap between the theory and the results of the study where the complaints felt by the patient and the results of the assessment that had been obtained were both appropriate.

\section{Nursing diagnoses}

Based on the data obtained in the assessment focused on Mrs. S and Mrs. $A$, the authors conclude that the appropriate nursing diagnoses are: knowledge deficit related to the inability of the family to recognize sick family members. Knowledge deficit is the result of human sensing, or the result of someone knowing about objects through the senses they have (eyes, nose, ears, and so on). So knowledge is various kinds of things that are obtained by a person through the five senses.

The author formulated this diagnosis because Mrs. S with hypertension did not know the meaning of hypertension. Characterized by the patient saying that he does not know what hypertension is and its treatment. Meanwhile, Mrs. A with the patient said that she did not know what hypertension was and its treatment. Therefore, this diagnosis is the main task of providing health education, because health education provides a lifestyle to reduce hypertension

\section{Intervention}

Based on knowledge deficit nursing problems related to knowledge deficits, 
the authors plan nursing actions to find out what happened with the aim that after nursing actions for $1 \times 24$ hours the patient is expected to understand and treat hypertension. At the intervention stage, the author prepares a nursing care plan for Mr. S and Mr. A, which is to provide health education about hypertension. The purpose of providing health education is so that patients understand the meaning of hypertension to traditional medicine. Health education is a conscious effort to cause changes in healthy living behavior, both in the community and social environment.

\section{Implementation}

Nursing implementation is a series of activities carried out by nurses to help clients from health status problems to better health status that describes the expected outcome criteria (Potter \& Perry 2011). At the implementation stage, the authors carried out an intervention that had been planned in advance to overcome the problem of lack of knowledge in Mrs. S and Mrs. A with hypertension. When this health education was given, the respondents followed the directions given to make traditional medicine from star fruit to lower blood pressure. Supporting factors: Mrs. S and Mrs. A listen to educational activities, Mrs. S and Mrs. A patients want to take starfruit Infused water therapy treatment and cooperative patients. Inhibiting factor: The situation in Mrs. S and Mrs. A is noisy when doing health education.

\section{Evaluation}

Evaluation is the last step of the nursing process to determine the extent to which the goals of the nursing plan have been achieved. This evaluation is done by comparing the observed final results with the goals and outcome criteria made in the nursing plan. Is the nursing care provided to the client successful in overcoming the problem. To determine the level of success of nursing actions that provide Health Education. Mrs.S got the results before giving Health Education, Ny.S blood pressure was $145 / 80 \mathrm{mmHg}$ and after Health Education the blood pressure was $140 / 80 \mathrm{mmHg}$. While Mrs. A got the results before explaining Health Education, Mr. A's blood pressure was $140 / 80 \mathrm{mmHg}$ and health education was carried out on the results of blood pressure 135/80 $\mathrm{mmHg}$.

\section{Conclusion}

Knowledge deficit is the result of human sensing, or the result of someone knowing about objects through the senses they have (eyes, nose, ears, and so on). So knowledge is various kinds of things that are obtained by a person through the five senses. At the implementation stage, the authors carried out an intervention that had been planned in advance to overcome the problem of lack of knowledge in Mrs. $\mathrm{S}$ and Mrs. A with hypertension. When this health education was given, the respondents followed the directions given to make traditional medicine from star fruit to lower blood pressure. Supporting factors: Mrs. S and Mrs. A listen to health education activities, Mrs. S and Mrs. A patients want to take starfruit Infused water therapy treatment and cooperative patients. Inhibiting factor: The situation in Mrs. S and Mrs. A is noisy when doing health education.

Evaluation is the last step of the nursing process to determine the extent to which the goals of the nursing plan have been achieved. This evaluation is done by comparing the observed final results with the goals and outcome criteria made in the nursing plan. Is the nursing problem resolved?. 


\section{References}

Ackley, B.J., Ladwig, G.B., \&Makic, M. B. F. (2017). Nursing Diagnosis Hanbook, An Evidence-Based Guide to Planning Care.

Andarmoyo, S. (2016). Keperawatan Keluarga : Konsep Teori, Proses dan Praktik Keperawatan. Yogyakarta : Graha Ilmu. Ardiansyah, M. (2012).Medikal Bedah. Yogyakarta : DIVA Press

Friedman, M. (2010). Buku Ajar Keperawatan Keluarga : Riset, Teori dan Paktek Edisi ke-5. Jakarta : EGC.

Herdman, T.H., \& Kamitsuru, S. (2014). Nursing Diagnosa dan klasifikasi.

Kandarini, Y. (2017). Tatalaksana Farmakologi Terapi Hipertensi.PKB-Trigonum

Sudema-Ilmu Penyakit Dalam XXV.

Nursalam.

Metodologi Ilmu Keperawatan, ed isi 4, Jakarta: Salemba Medika.

Mubarak, IW. 2012. Ilmu Kesehatan Masyarakat. Jakarta: Salemba. Medika.

Prastanti, Dhian Wahyu. (2012). Konsep Keperawatan Keluarga. Universitas Purwokerto: Muhammadiyah.

Price and Wilson. 2005. Konsep Klinis Proses-Proses Penyakit Edisi 6. Vol.2.Jakarta: EGC.

Riskesdas. 2013. Riset Kesehatan Dasar; RISKESDAS. Jakarta: Balitbang DepkesRI.

Rahajeng E . (2011). Prevalensi Hipertensi Dan. Determinannya Di Indonesia. Jakarta: PT Gramedia Pustaka Utama.

Suprajitno. (2012). Asuhan Keperawatan Keluarga. Jakarta : EGC.
Setiadi. 2008. Konsep dan Keperawatan Keluarga. Yogyakarta: Graha Ilmu.

Tim Pokja SDKI DPP PPNI. (2016). Standar Diagnosis Keperawatan Indonesia Definisi dan Indikator Diagnostik. Jakarta: Dewan Pengurus PPNI.

WHO. World Health Statistics 2012: World Health Organization; 2012.

WHO. World Health Statistics 2015: World Health Organization; 2015. (Diakses 23 Agustus 2021)

P2PTM Kemenkes RI. (2019). Bagaimana mengurangi risiko hipertensi?.http://www.p2ptm.ke mkes.go.id/infographicp2ptm/hipe rtensi-penyakitjantung-danpembuluhdarah/page/4/bagaimana -mengurangi-risiko hipertensi. (Diakses 24 Agustus 2021).

RKD:http://labmandat.litbang.depkes.go .id/images/download/laporan/RK D/2018Laporan_Nasional_RKD2 018_FINAL.pdf. (Diakses pada 25 Agustus 2021).

https://simdos.unud.ac.id/uploads/file_p enelitian1_dir/91ce253ff5aa007ba 1

cc8d5d19cfe3f4.pdf Kemeterian kesehatanRI.(2019). 